\section{Organizing the Kentucky Horticulture Industry for Improved Strategic Planning and Representation}

\author{
Dewayne L. Ingram ${ }^{1}$
}

ADDITIONAL INDEX WORDs. advisory council, coalition, leadership, extension

Summary. The University of Kentucky's Department of Horticulture, led by the extension faculty working with targeted industry associations, facilitated the creation of the Kentucky Horticulture Council to be the voice of a diverse industry. Leadership in industry strategic planning, promoting the opportunities for expansion of the horticulture industry, and educating state agriculture, legislative and university leaders provided a focus of energy and positioned the industry to access emerging resources. Leadership development has been an anticipated byproduct of this process.

L ike many states, Kentucky's horticulture industry is diverse and important to the agricultural economy (Woods, 2009a; Woods and Williamson, 2008). However, the agricultural infrastructure and traditions are dominated by other industry segments such as burley tobacco $(\mathrm{Ni}$ cotiana tabacum), horses, and cattle. Forage and livestock interests are paramount in Kentucky with regard to state resource allocations.

The interests of Kentucky horticulture are represented by 13 industry and professional associations. Before 1991, each of these organizations approached state governmental agencies and universities representing a relatively small constituency. Stories of state legislators pitting one horticultural organization against the other were common.

It was determined that limiting factors in the growth of the industry were the lack of visibility and an underdeveloped statewide production and marketing infrastructure, including research and extension programs through the land grant universities. The University of Kentucky (UK) Department of Horticulture wanted an industry advisory group, but the industry coordination needs were even greater. It was anticipated that this situation could be improved by focusing the industry's diverse efforts through a single, more powerful voice such as had been observed for the Kentucky Cattlemen Association.

Department of Horticulture, University of Kentucky, N-318 Ag Science North, Lexington, KY 405460091

${ }^{1}$ E-mail: dingram@uky.edu.
The industry looked to the UK College of Agriculture for production and marketing research and education and to the Kentucky Department of ment and market promotion. Although $\mathrm{UK}$ and $\mathrm{KDA}$ worked well together to benefit the industry, both lacked the resources to meet the expanding needs and opportunities.

\section{Approach}

In an effort to organize a unified front for the industry, information about how industry groups were organized in other states was sought through informal communication with horticulture departmental administrators in 1990 and 1991. Generally, states with large, established individual commodities used the strength of those individual associations and some had market orders in place to fund promotion as well as research and extension programs. In some cases, leaders from those targeted associations served as an advisory group for the horticulture departments in those states. The horticulture departments in several states with smaller individual commodity groups used advisory groups comprised of invited industry leaders from the various industry segments. Marketing orders for the diverse industries in those states were rare. Ideas generated by the discussions with colleagues were used to craft a framework that seemed to fit the Kentucky situation.

Important in the initiation of this process to form an umbrella organization was the relationships already forged between the individual extension faculty members and industry Agriculture (KDA) for market develop- leaders and the interest and attention of a new department chair. After conversations between the department chair and individual industry association leaders, the UK Department of Horticulture, with the support of College of Agriculture administration, hosted a meeting of the leadership of all the horticulture-related organizations in 1991 to discuss the future of horticulture in the state and how they might collectively better impact the industry. The industry associations invited were: Kentucky State Horticulture Society (fruit growers), Kentucky Nursery and Landscape Association, Kentucky Arborists' Association, Kentucky Vegetable Growers' Association, Kentuckiana Greenhouse Association, The Garden Club of Kentucky, Inc., Kentucky Nut Growers' Association, Kentucky Vineyard Society, Louisville Nursery Association, Central Kentucky Ornamental and Turf Association, Kentucky Florists Association, and Kentucky Turfgrass Council. The concept of an umbrella organization was presented as a framework for the discussion at this meeting.

Facilitated discussion at this organizational meeting resulted in the formation of the Kentucky Horticulture Council (KHC) as a broad coalition with a multifaceted purpose to: 1) provide an avenue for the various segments of Kentucky horticulture to focus on common issues; 2) promote Kentucky horticulture to Kentucky citizens, state legislators, Kentucky's congressional delegation, university leaders, and other state and federal agencies; and 3) interact with and foster and organize support for the statewide research, extension, and teaching programs of UK related to horticulture, the horticulture teaching programs at the regional universities, and vocational horticulture teaching programs in Kentucky. The KHC was to consist of the president and a representative of each member association.

The next step was to develop a strategic plan for the industry by first more clearly defining the current status of the industry. A multidisciplinary team of faculty provided the required data on the status of the industry segments and the Kentucky and U.S. consumer demands and market opportunities. The faculty worked with individual industry associations to answer three important questions: What is the potential for the industry? 
What are the limiting factors to industry growth? What would it take to achieve industry goals? Member association leaders brought their answers to these questions to $\mathrm{KHC}$ meetings where the information and ideas initiated the framework of a strategic plan. A facilitated discussion approach allowed faculty to input information without limiting industry imagination, insight, and suggestions. The overall atmosphere created recognition that segments of the industry were not in competition but could gain mutual support through collaboration. Expansion of the state industry was necessary for most of the existing industry to gain access to markets and increase the size of the market. The local and U.S. markets were expanding and the Kentucky horticulture producers wanted to gain their fair share of that increase (Woods, 2009b).

The development of this strategic plan was fortuitously followed by strategic planning for Kentucky agriculture as a whole led by UK, KDA, and the Kentucky Farm Bureau. This effort by the agriculture sector in 1992 provided a stage for KHC to present the horticulture industry's potential and constraints to the state leaders and lead organizations and agencies.

\section{Results}

The strategic plan, Horticultural Opportunities: A Prospectus for Kentucky Horticulture, was first drafted in 1992 and updated every 2 to 3 years (unpublished data). The KHC leaders presented the plan to state legislative committees, UK administrators, and state agriculture leaders, including the Kentucky Farm Bureau. Every opportunity was taken to educate state agency personnel and state legislators of the potential and constraints for Kentucky horticulture. The secondary benefit from these activities was the solidification of the $\mathrm{KHC}$ as the recognized, respected voice of Kentucky horticulture. It basically took a decade to accomplish this. Important to the UK Department of Horticulture was the building of a relationship between the KHC leadership and UK College of Agriculture administrators.

Successful lobbying of state agency leaders and the state legislature included such topics as the official identification of horticulture as part of agriculture in state statutes and agency policies and procedures. As simple as this might seem, it yielded great benefits for individual producers relative to water rights, zoning issues, taxes, and representation on state committees and boards. Policy was secured to direct state agencies to give Kentuckygrown produce and plants a high priority in their purchases. This included the restaurants in the state resort parks. The nursery crop inspection program has been greatly expanded with $\mathrm{KHC}$ support. The KHC assisted the Kentucky Vineyard Society in gaining changes in Kentucky laws and policies that were greatly hampering the expansion of that industry. For example, "farm" wineries were defined and licensed. The success of other lobbying efforts has been mixed but continuing.

The KHC organizes a day in the state capitol annually to meet individually with legislators and present updates to key legislative committees. A simple, two-sided pocket card highlighting the value of the industry and their key legislative issues is distributed on that date. Horticulture industry representatives are identified by a large KHC lapel button as they move through the halls of the capitol.

Lobbying efforts were making progress toward gaining targeted state funds to support research and extension programs at UK as well as market development and marketing assistance through KDA when the Master Tobacco Settlement awarded significant funds to the state. The state chose to dedicate $50 \%$ of those funds to support agriculture and rural communities, particularly those counties highly dependent on tobacco income. The KHC was well prepared with its prospectus for Kentucky horticulture to be the first organization to apply for those funds in 2001. That proposal and four others since then have been funded for more than $\$ 9$ million, almost $\$ 6$ million of that supporting UK horticulture extension and research programs. State funds had never been targeted to the UK horticulture programs before this.

For the KHC to receive and handle grant funds, it secured a 501(c)(5) IRS status. Legal counsel was required for this and it was determined to seek “(c)(5)" status. That allowed the KHC to function as an official not-for-profit corporation and continue its lobbying efforts. This status does not allow for acceptance of tax-free donations.
Over the last decade, the Kentucky's horticulture industry has grown $8 \%$ to $10 \%$ per year, until the economic downturn in 2008 and 2009 (Woods, 2008). Many new growers are engaged in the industry and many operations have expanded (Woods and Williamson, 2008). Retail markets have grown exponentially as has niche markets such as restaurants and local food services. Growers are accessing regional and national markets. The grant-funded programs at UK and KDA have supported that level of growth. A rebound in the industry as a whole appears to be occurring in 2010 with a strong demand for assistance by new growers initiating horticultural enterprises targeting local growth markets.

\section{Discussion}

The KHC has become the visible representative of the horticulture industry to university administration, state agencies, and the state legislature. Not all the member associations are as active as others in the KHC, but all recognize that coordination and collaboration are keys to their individual and collective success. Industry leaders, supported by the UK Department of Horticulture, have blossomed personally and the horticulture industry's influence in the state has grown significantly since the $\mathrm{KHC}$ was formed in 1991. The UK Department of Horticulture provided logistical support of the KHC for almost two decades. In 2010 , the KHC hired a part-time Executive Director. That individual has assumed the logistic support role and is leading efforts to gain additional funding for the organization. The KHC can continue to be an important force for the industry, but any such coalition requires strong, committed leadership and operating funds from prosperous enterprises.

Key to this story is not the funding secured, but that the industry was organized, visible, persistent, and ready to seize the opportunity when funding was available. The UK Department of Horticulture, particularly the extension faculty, played a vital role in this achievement. As important as the $\mathrm{KHC}$ has been in providing valuable insight into industry needs and opportunities and securing funds for extension and research programs, leadership development through identifying, supporting, coaching, encouraging, and promoting key industry 
leaders may be the most lasting outcome.

\section{Literature cited}

Woods, T. 2008. Horticulture. In: L. Powers and J. Hunter (eds.). The Kentucky agricultural economic outlook for 2009. 20 June 2010. <http://www.ca.uky. edu/cmspubsclass/files/swilliamson/ group/AECoutlook2010.pdfs.
Woods, T. 2009a. Horticulture situation and outlook 2009-10. In: K. Burdine and S. Williamson (eds.). 2009-2010 Agricultural situation and outlook. ESM-35. 20 June 2010. <http://www.ca.uky.edu/ cmspubsclass/files/swilliamson/group/ 09esmPubFinal.pdf $>$.

Woods, T. 2009b. Horticulture. In: K. Burdine and S. Williamson (eds.). The economic outlook for Kentucky in
2010. 20 June 2010. <http://www.ca. uky.edu/cmspubsclass/files/jhunter/ $2009 \% 20$ Outlook.pdf>.

Woods, T. and S. Williamson. 2008. Produce outlook: Planting \& marketing for 2008-2009. In: K. Burdine and S. Williamson (eds.). Agricultural situation and outlook, Fall 2008. ESM-34. 20 June 2010. <http://www.ca.uky.edu/ cmspubsclass/files/esm/esm_34.pdf>. 